\title{
Specify Other BRAF Codon 600 Mutation
}

National Cancer Institute

\section{Source}

National Cancer Institute. Specify Other BRAF Codon 600 Mutation. NCI Thesaurus. Code C158889.

A request to enter the specific mutation involving BRAF codon 600 that was identified in the study but is not present in the form. 